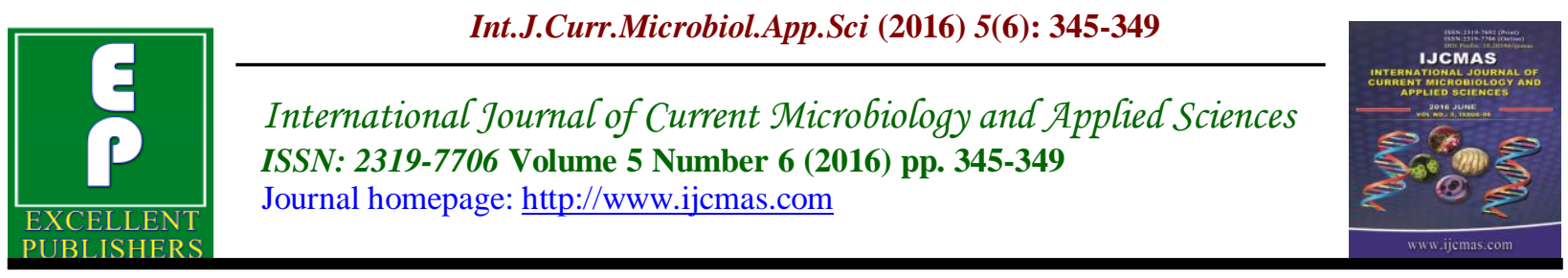

Original Research Article

http://dx.doi.org/10.20546/ijcmas.2016.506.039

\title{
Bacteriological Profile and Antimicrobial Sensitivity of DJ Stents
}

\author{
Devendra Singh Pawar $^{1}$, Seema Mittal ${ }^{2}$, Ashok Kumar ${ }^{1}$, Santosh Kumar Singh ${ }^{1}$ \\ ${ }^{1}$ Department Urology, Pt. B.D.S. PGIMS, Rohtak-124001, Haryana, India \\ ${ }^{2}$ Department of Microbiology, BPSGMC (w) Khanpurkalan, Sonepat, Haryana, India \\ *Corresponding author
}

\begin{tabular}{|c|c|}
\hline & A B S T R A C T \\
\hline $\begin{array}{l}\text { Ke y w o r d s } \\
\text { Double J stent, } \\
\text { Escherichia coli, } \\
\text { Antimicrobial } \\
\text { Sensitivity, } \\
\text { Staphylococcus. }\end{array}$ & \multirow{3}{*}{$\begin{array}{l}\text { The aim of this study is to investigate the bacteriology of urinary tract infection } \\
\text { associated with indwelling DJ stent. A total of } 50 \text { stents were included in the } \\
\text { study, during a period was for } 6 \text { months carried out in the department of } \\
\text { microbiology, PGIMS, Rohtak. Prophylactic antibiotic was given at the time of } \\
\text { intervention. Mid stream urine samples for routine and culture were sent before } \\
\text { intervention. Urine samples during DJ removal and DJ tip cultures were also sent. } \\
\text { All patients were "stented" during the various open and endourological procedures. } \\
\text { A total of } 50 \text { cases were included. Mean age in years was } 35.70 \text { (10- } 78 \text { years). Male } \\
\text { were } 24 \text { and female } 26 \text {. Of the pathogens identified, CONS was found to be the } \\
\text { most common. An increased stent colonization rate was associated with } \\
\text { implantation time, female sex. Positive urine culture and positive DJ tip cultures } \\
\text { had strong correlation. Longer duration of placement of stent showed stent } \\
\text { colonization. The commonest pathogen was Coagulase negative Staphylococcus. }\end{array}$} \\
\hline Article Info & \\
\hline $\begin{array}{l}\text { Accepted: } \\
\text { 15 May } 2016 \\
\text { Available Online: } \\
10 \text { June } 2016\end{array}$ & \\
\hline
\end{tabular}

\section{Introduction}

Insertion of the Double-J (DJ) catheter into the ureter, which facilitates drainage of the upper urinary tract, is one of the most common urological procedures. (Damiano et al., 2002)

The most common problems associated with indwelling ureteral devices are encrustation, bacterial adhesion and biofilm formation on the device surface. Even in patients in whom infection does not develop, bacteria are often isolated from the stent surface despite the collection of sterile urine. (Akay et al., 2007)

Information about the incidence of colonization by different microorganisms and their drug susceptibility pattern may play an important role in treatment of such infections. (Safdar et al., 2004) The main of this study includes, to assess the frequency of ureteral stent colonization and to find out the microorganisms associated with stent colonization and antimicrobial sensitivity pattern of the isolates from double-J stent, to develop an approach for prevention of urologic devices associated colonization.

\section{Material and Methods}

The study was conducted in the Department of Microbiology, Pt. B.D. Sharma, PGIMS Rohtak during a period of 6 months from 
April 2015 to September 2015. Fifty double $\mathrm{J}$ stents were included in the study. These stents were indicated in patients for different indications for example extracorporeal shortwave lithotripsy, post ureteroscopy, endoureterotomy etc. The average indwelling time was two weeks and varied depending upon the indication of individual patient. At the time of insertion three days of oral antibiotics were given. Urine samples, were collected aseptically before insertion of stent and before removal of stent. Semi-quantitative method of culture was performed with urine samples by the standard laboratory procedure using a calibrated loop $(0.01 \mathrm{ml})$.

Tip end of the devices were taken aseptically, and then thoroughly washed with phosphate buffer saline $(\mathrm{pH}$ 7.2) to remove non-adherent cells. The devices were dipped into the tubes containing $5 \mathrm{ml}$ brain heart infusion (BHI) broths and incubated at $37^{\circ} \mathrm{C}$ for $24 \mathrm{~h}$. One loopful of broth from each tube was subcultured on blood agar plates. Isolated colonies were provisionally identified based on growth characteristics, morphology, motility and biochemical test results. (Collee et al., 2006)

Antimicrobial susceptibility tests for all bacterial isolates were performed by KirbyBauer disc diffusion method. (Wayne, 2007)

\section{Results and Discussion}

A total of 28 microorganisms were isolated from DJ stents. Out of which, Escherichia coli was the predominant organism. CONS, Enterococcus, Acinetobacter spp., pseudomonas aeruginosa, Staphylococcus aureus, Citrobacter spp., Enterobacter spp. and Proteus spp. were other organisms.

Antibiotic sensitivity of staphylococcus isolates showed $100 \%$ sensitivity to Erythromycin, Cefoxitin, Norfloxacin, Nitrofurantoin and Linezolid. CONS showed maximum sensitivity to Nitrofurantoin and Linezolid. Antibiotic sensitivity of Enterococcus isolates showed maximum sensitivity to Linezolid and Vancomycin.

In our study, members of Enterobacteriaceae showed maximum sensitivity to fosfomycin, gentamicin, imipenem and meropenem.

Non fermenters showed maximum sensitivity to Fosfomycin and PiperacillinTazobactam.

The current advances in minimally invasive surgery such as extracorporeal shock wave lithotripsy and endourologic surgery increases the use of internal stents in urological procedures. Many complications are commonly found during the placement of internal ureteral stent placement such as DJ symptoms, migration, encrustation, fragmentation, urinary tract infection. Stent bacterial cololnization is one of the most important complication.

Table.1 Number of stents with microbial growth

\begin{tabular}{|c|c|}
\hline Total number of stents & 50 \\
\hline Sterile stents & 24 \\
\hline Stents with monomicrobial colonisation & 24 \\
\hline Stents with polymicrobial colonisation & 4 \\
\hline
\end{tabular}


Table.2 Organisms isolated from culture positive double $\mathrm{J}$ stent

\begin{tabular}{|c|c|c|c|}
\hline \multirow{2}{*}{ Name of Microorganism } & \multicolumn{3}{|c|}{ Double J Stent (n= 50) } \\
\cline { 2 - 4 } & Pure & Mixed & Total \\
\hline Staphylococcus aureus & 2 & 0 & 2 \\
\hline $\begin{array}{c}\text { Coagulase negative } \\
\text { staphylococcus(CONS) }\end{array}$ & 5 & 0 & 5 \\
\hline Enterococcus & 3 & 1 & 4 \\
\hline Escherichia coli & 6 & 1 & 4 \\
\hline Acinetobacter spp. & 3 & 1 & 3 \\
\hline Pseudomonas aeruginosa & 3 & 0 & 1 \\
\hline Citrobacter spp. & 1 & 0 & 1 \\
\hline Enterobacter spp. & 1 & 0 & 28 \\
\hline Proteus spp. & 0 & 1 & 1 \\
\hline Total & 24 & 4 & \\
\hline
\end{tabular}

Table.3 Antibiotic sensitivity of Staphylococcus spp. Isolates

\begin{tabular}{|c|c|c|c|c|}
\hline \multirow{2}{*}{$\begin{array}{c}\text { Name of } \\
\text { Antibiotic }\end{array}$} & \multicolumn{3}{|c|}{ Staphylococcus aureus $(\mathrm{n}=2)$} & \multicolumn{2}{c|}{$\begin{array}{c}\text { Coagulase negative Staphylococcus } \\
(\mathrm{n}=5)\end{array}$} \\
\cline { 2 - 5 } & Sensitive & Resistant & Sensitive & Resistant \\
\hline Erythromycin & 2 & 0 & 0 & 5 \\
\hline Doxycycline & 1 & 1 & 2 & 3 \\
\hline Cefoxitin & 2 & 0 & 0 & 5 \\
\hline Norfloxacin & 2 & 0 & 2 & 3 \\
\hline Nitrofurantoin & 2 & 0 & 5 & 0 \\
\hline Linezolid & 2 & 0 & 5 & 0 \\
\hline
\end{tabular}

Table.4 Antibiotic sensitivity of Enterococcus spp. Isolates

\begin{tabular}{|c|c|c|}
\hline \multirow{2}{*}{ Name of Antibiotic } & \multicolumn{2}{|c|}{ Enterococcus spp. (n=4) } \\
\cline { 2 - 3 } & Sensitive & Resistant \\
\hline Cephalexin & 0 & 4 \\
\hline Gentamicin & 0 & 4 \\
\hline Doxycycline & 0 & 3 \\
\hline Nitrofurantoin & 1 & 0 \\
\hline Linezolid & 4 & 0 \\
\hline Vancomycin & 4 & \\
\hline
\end{tabular}


Table.5 Antibiotic Sensitivity of Enterobacteriaceae $(n=10)$

\begin{tabular}{|c|c|c|}
\hline Name of Antibiotic & Sensitive & Resistant \\
\hline Amikacin & 4 & 6 \\
\hline Gentamicin & 9 & 1 \\
\hline Imipenem & 9 & 1 \\
\hline Meropenem & 9 & 1 \\
\hline Ofloxacin & 2 & 8 \\
\hline Norfloxacin & 3 & 7 \\
\hline Ceftizoxime & 4 & 6 \\
\hline Nitrofurantoin & 8 & 2 \\
\hline Amoxyclav & 8 & 2 \\
\hline Piperacillin- Tazobactam & 9 & 1 \\
\hline Fosfomycin & 10 & 0 \\
\hline
\end{tabular}

Table.6 Antibiotic sensitivity of Nonfermenters (Pseudomonas aeruginosa and Acinetobacter spp.) (n=7)

\begin{tabular}{|c|c|c|}
\hline Name of Antibiotic & Sensitive & Resistant \\
\hline Amikacin & 3 & 4 \\
\hline Gentamicin & 1 & 6 \\
\hline ceftizoxime & 1 & 2 \\
\hline Imipenem & 5 & 2 \\
\hline Meropenem & 5 & 3 \\
\hline Ofloxacin & 4 & 4 \\
\hline Norfloxacin & 3 & 4 \\
\hline Nitrofurantoin & 3 & 0 \\
\hline Fosfomycin & 7 & 0 \\
\hline Piperacillin- tazobactam & 7 & 6 \\
\hline
\end{tabular}

The bacteriuria and bacteremia may occur from colonization because colonization can serve as a nidus for bacteriuria that play an important role in stent associated infection. Bacterial colonization has been seen to increase after 2 weeks of indwelling stent and followed by urine colonization. Longer the duration of DJ placement, more the rate of colonization seen. (Kehinde et al., 2004) Similar observation was made in our study.

In this study, the bacterial colonization was positive in $52 \%$ of the stents. In another study conducted by Kehinde et al, bacterial colonization was positive in $42 \%$ of stents.

Commonest pathogen was Coagulase negative Staphylococcus where Paich C H et al found to be Enterococcus species. Sterile urine does not rule out stent colonization. Diabetes Mellitus, chronic renal failure, malignancy, pregnancy are high risk factors which was not addressed in our study. These patients need to be carefully monitored for stent-related complications and use of prophylactic antibiotic. (Niël-Weise et al., 2005; Akay et al., 2007)

\section{References}

Damiano, R., Oliva, A., Esposito, C., De Sio, M., Autorino, R., D'Armiento, M. 2002. Early and late 
complications of double pigtail ureteral stent. Urol. Int., 69: 136-40.

Akay, A.F., Aflay, U., Gedik, A., Sahin, H., Bircan, M.K. 2007. Risk factors for lower urinary tract infection and bacterial stent colonization in patients with a double J. Ureteral Stent., Int. Urol. Nephrol., 39: 95-8.

Safdar, N., Maki, D.G. 2004. The pathogenesis of catheter-related bloodstream infection with noncuffed short-term central venous catheters. Intensive Care Med., 30: 62-7.

Collee, J.G., Miles, R.S., Watt, B. 2006. Tests for the identification of bacteria. In: Collee JG, Marmion BP, Fraser AG, Simmons A, editors. Practical Medical Microbiology. 14th ed. Churchill Livingstone, Imprint of Elsevier India; pp. 131-78.

Wayne, P.A. 2007. Clinical and Laboratory Standard Institute. Clinical and Laboratory Standard Institute. Performance Standard for Antimicrobial Susceptibility Testing; Sixteenth Informational Supplement; pp. M100-S17.
Lojanapiwat, B. 2006. Colonization of internal ureteral stents and bacteriuria. W J. Urol., 24: 681-3.

Kehinde, E.O., Rotimi, V.O., Al-Hunayan, A., Abdul-Halim, H., Boland, F., AlAwadi, K.A. 2004. Bacteriology of urinary tract infection associated with indwelling $\mathrm{J}$ ureteral stents. $J$. Endourol., 18(9): 891-6.

Paick, S.H., Park, H.K., Oh, S.J., Kim, H.H. 2003. Characteristics of bacterial colonization and urinary tract infection after indwelling of double-j ureteral stent. Urol., 62(2): 214-7.

Niël-Weise, B.S., van den Broek, P.J. 2005. Antibiotic policies for shortterm catheter bladder drainage in adults. Cochrane Database Syst. Rev., 20(3): CD005428.

Akay, A.F., Aflay, U., Gedik, A., Sahin, H,. Bircan, M.K. 2007. Risk factors for lower urinary tract infection and bacterial stent colonization in patients with a double $\mathrm{J}$ ureteral stent. Int. Urol. Nephrol., 39(1): 95-8.

\section{How to cite this article:}

Devendra Singh Pawar, Seema Mittal, Ashok Kumar, Santosh Kumar Singh. 2016. Bacteriological Profile and Antimicrobial Sensitivity of DJ Stents. Int.J.Curr.Microbiol.App.Sci. 5(6): 345-349. doi: http://dx.doi.org/10.20546/ijcmas.2016.506.039 